\title{
Stories of Morals: "Governing the Country After Cultivating One's Moral Character and Managing the Family's Affairs Well”
}

\section{A Half QuilT}

In essence, the Long March told the story of a deep emotional bond between the Red Army and the people. When passing through Shazhou Village in Rucheng County, Hunan Province, three female Red Army soldiers sought shelter in the home of an elderly villager named $\mathrm{Xu}$ Jiexiu. Upon their departure, they cut their only quilt in two, leaving half with Xu Jiexiu. The elderly Xu said, "Who are the Communist Party members? They are those who have only one quilt but give half to the people."

- Speech at the Convention to Commemorate the 80th Anniversary of the Victory of the Red Army's Long March (October 21, 2016).

\section{Commentary}

Never give up on the people, and go hand in hand with the people forever. The "quilt cut in half" narratively evidences the close relationship between the Red Army soldiers and the people and symbolizes interdependence between the CPC and the masses.

The story took place in November 1934, when the Central Red Army broke the second blockade of the Kuomintang army and the legions arrived 
in Wenming Village, Rucheng County, Hunan province in succession and were quartered on Wenming, Xiushui, Hantian, and Shazhou for a week of rest and recuperation. It was during this period that three exhausted women soldiers of the Red Army sought shelter in a dilapidated cottage at the edge of Shazhou Village. This cottage was the home of Xu Jiexiu and her husband. Being utterly destitute, the couple had only a bedstead made of bamboo, with a meager covering of rice straw and a tattered grass mat serving as mattress. They did not even have a complete quilt. When sleeping, they could only cover themselves in a ragged pile of rotten cotton batting. Such being the case, the woman soldiers, who had abandoned all their baggage during the rapid march with the exception of a single quilt, squeezed up on this bed and shared the quilt with the hostess at night as they slept, while the male host of the cottage had to sleep on the haystack at the door to guard them.

The soldiers not only helped Xu Jiexiu and her husband tend the kitchen fire and cook meals but they also taught them revolutionary philosophies at their leisure. After sharing a bed with $\mathrm{Xu}$, eating at the same table with the couple and performing manual labor together with them for several days, the soldiers had to say goodbye to them and continue to march on. In the early morning of the parting day, they decided to leave their only quilt to the couple, while the couple graciously declined it. The elderly couple continued to decline out of modesty all the way until they saw the soldiers off at the village entrance. Then, one of the soldiers took a pair of scissors from her backpack and cut the quilt in half, and said to Xu, "After we win the victory of the revolution, we will definitely present a complete new quilt to you." Accepting the half quilt, Xu felt a lump in her throat, and her eyes brimmed with tears.

The fellows of the Red Army spread all over the road of the Long March, their stories famously including "the old peasant living in the soviet area who sent all eight of his sons to join the Red Army," "the boatmen who risked their lives to ferry the Red Army soldiers over the Dadu River," and "the Tibetans living in the Qiaoqi Tibetan Town who set three memorial gateways composed of pines and cypresses as well as fresh flowers to greet the Red Army." They were the unsung heroes of the Long March.

At the Convention to Commemorate the 80th Anniversary of the Victory of the Red Army's Long March, Xi Jinping narrated the story of the half quilt that took place during the Long March, asserting that "the Long March succeeded because the CPC and the Red Army stood together with the people, maintained a close bond with the people, and shared weal and 
woe with the people," and warning the whole Party that to carry forward the spirit of the Long March and to succeed in our present long march, we must put the people at the very center of our hearts and remain committed to serving the people and relying on them in all of our endeavors.

\section{Emperor Kangxi Disfavored the Lingzhi Mushroom}

The rulers of the past dynasties paid close attention to doing pragmatic work and implementing governance with pragmatism. Once, the Governor of Guangxi Province, Chen Yuanlong, reported to Emperor Kangxi that "a cloud-like Lingzhi mushroom over $33 \mathrm{~cm}$ high was plucked in a mountain in Guilin," and he quoted the words in the book Shen Nong's Classic, "The benevolent monarchs encourage the growth of the Lingzhi mushroom." Kangxi gave the following in reply: "There have been numerous indications of auspiciousness and disaster recorded in the annals of history. However, none of them had a use for the national welfare and the people's livelihood. No auspicious sign is greater than good crops from place to place as well as families living in affluence." He also once wrote, "The auspicious signs recorded in the historical annals, such as the propitious star, colored cloud, kirin and phoenix, and Lingzhi mushroom as well as tales of burning jewelry and jade in front of the hall and the sealed book coming down from heaven to the Chengtian Gate were all unreal and absurd writings, which I consider undesirable. I solely focus on the pragmatic administration of the people's livelihood in all sincerity." The ancient rulers also knew that if officials at all levels were not pragmatic, the people would not live well and live on, and consequently their feudal regimes would collapse.

- Speech at a Meeting for Criticism and Self-criticism of the Political Bureau of the 18th CPC Central Committee on the "Three Guidelines for Ethical Behavior and Three Basic Rules of Conduct" (December 28 to 29,2015$)$.

\section{Commentary}

In ancient China, there was a theory of "telepathy between man and nature," claiming that the auspicious signs in nature symbolize the clean and bright government. The feudal emperors therefore looked forward to the presence of so-called "auspicious signs". This offered an opportunity 
for sycophants to crawl out and flatter the monarchs with fake auspicious signs.

In 1713, the 52nd year of the reign of Kangxi, Huang Guocai, the Administrative Commissioner of Guangxi Province, reported to the Governor of Guangxi Chen Yuanlong that a cloud-like Lingzhi mushroom over $33.3 \mathrm{~cm}$ high had been plucked on a mountain of Guilin that February. He asked a favor of Chen to present this specimen to the emperor. Chen immediately sent a person to deliver it to the imperial palace, with a memorial attached. He indicated the "theory of auspicious sign" by quoting the classics and flattered Kangxi that the mushroom was an outcome of his benevolent governance. Knowing that Emperor Kangxi disliked socalled auspicious signs, but still going out of his way to deliver a harangue on it, Chen Yuanlong said a few words of flattery on Kangxi's birthday. Unexpectedly, Kangxi expressed his displeasure with the statement, and he declared that such a matter was so meaningless that there was no need for him to read the report on it.

Similarly, in the 56th year of Kangxi's reign, the Viceroy of Zhili Zhao Hongxie reported that a Lingzhi mushroom grew in his neighbor's yard. He stated, "A Lingzhi mushroom has arrived to presage auspiciousness under both reigns of Emperor Yao of the state of Tang as well as Emperor Shun of the state of Yu. Yet Your Majesty is much more virtuous and much more benevolent towards the people than Yao and Shun, so that people all over the world are bathing in the bounties bestowed by Your Majesty. Therefore, it is reasonable that the Lingzhi mushroom would grow at this time." Disagreeing with Zhao, Kangxi wrote a comment in red: "What does auspiciousness refer to? A bumper harvest and an abundance of food for the people. These are the most favorable auspices." He also pointed out to Zhao that, "This is a truth that is very easy to understand; thus, there is no need to debate about it."

Kangxi considered "good crops from place to place as well as families living in affluence" and "a bumper harvest and an abundance of food for the people" as the most favorable auspicious signs instead of embracing the vain theory that "the auspicious sign is endowed by heaven." His statements were intended to promote the practice of pragmatic governance in all sincerity.

Xi Jinping told the story of "Emperor Kangxi disfavored the Lingzhi mushroom" with the intention of stressing the practice of carrying out pragmatic governance in all sincerity and warning the leading officials of the 
CPC that even the ancient rulers knew that if the officials at all levels were not pragmatic, the people would not live well and live on, and consequently their feudal regimes would collapse. He once recalled the precious insight he had when he was living and working in a production team in Yan'an, "I got to know what 'reality' meant, what 'seek truth from facts' meant, and what 'the masses' meant. This has benefitted me all my life." Therefore, the precept to "always act on the basis of seeking truth from facts" became the basic principle to which he adheres while pondering problems, making decisions, and handling affairs. He often encourages others to "do less unpragmatic work" and "be more pragmatic in planning, starting a business and behaving ourselves." The story of "Emperor Kangxi disfavored the Lingzhi mushroom" properly teaches the leading officials of the Party to be pragmatic and perform solid work.

\section{Self-cultivation Is the Priority-Among-Priorities FOR STATESMEN}

The Chinese have been emphasizing self-cultivation since ancient times. We believe that "From the Son of Heaven down to the mass of the people, all must consider the cultivation of the person the root of everything else"; "Cultivate oneself and thus bring peace and security to the people"; "To enter politics, a person should first cultivate his moral character and enrich himself with virtues"; and "One should behave himself on the basis of a pure thought and from the starting point of self-cultivation." For example, in the Warring States period, Zou Ji, an official of the state of Qi, persuaded the King Wei of Qi to encourage remonstrance against himself by citing the instance when he compared himself in handsomeness with $\mathrm{Mr}$. Xu who resided in the north of the city; Zhuge Liang came to the conclusion in The First Memorial to the King Before Setting off for War that "The emperors supported the virtuous and able officials and kept away from the vile and mean ones; thus, the Western Han Dynasty was prosperous. The emperors supported the vile and mean officials and kept away from the virtuous and able ones; thus, the Eastern Han Dynasty collapsed"; Fan Zhongyan contributed great lines through his essay The Yueyang Tower- "Be not thrown into ecstasies over success, nor feel depressed over failures" and "To be the first in the country to worry about the affairs of the state and the last in the country to enjoy oneself"; Wen Tianxiang wrote the heroic verse on the subject of life, "Since no one lives forever; I will leave only a loyalist's name in history." "One cannot be led into dissipation by wealth 
and rank, nor swerved from his aim by poverty and obscurity, nor subdued by power and force." Such characteristics of a great man were advocated by our ancestors.

- Speech at a Meeting for Criticism and Self-criticism of the Political Bureau of the 18th CPC Central Committee on the "Three Guidelines for Ethical Behavior and Three Basic Rules of Conduct", (December 28-29, 2015).

\section{Commentary}

The Confucian culture in ancient China emphasized "the supreme morality internalized as cultivation and externalized as the governance of virtue." "Internalized as cultivation" refers to one's inner morality. It means that one can become a qualified ruler only by cultivating his morality and forging his character. Zou Ji, Zhuge Liang, Fan Zhongyan, and Wen Tianxiang were all historical figures famous for supreme morality and moral integrity.

Zou Ji, an official of the state of Qi in the Warring States period, was tall and very handsome. When he asked his wife, concubine, and guest, respectively, "Who do you think is more handsome, $\mathrm{Mr}$. Xu (who is popular in town for his handsomeness) or I," all three told him that he is more handsome. But one day when Zou Ji eventually met Mr. Xu, he realized that $\mathrm{Mr}$. Xu is actually much more handsome than himself. So he asked himself why his wife, concubine, and friend wouldn't tell him the truth. Then, he concluded the reason for this distorted information: "my wife favored me," "my concubine was afraid of me and therefore wanted to please me," and "my guest asked me for help." In view of this, he realized that to govern the country, the ruler should encourage the free airing of views. Thus, he persuaded King Wei of Qi to encourage remonstrance against himself with an open mind and listen to advice from all parties. This initiative subsequently promoted Qi to hold hegemony over all other contender states. Today, we can find the article Zou Ji Persuaded the King Wei of Qi to Encourage Remonstrance Against Himself in Chinese middle-school textbooks. Zhuge Liang's tales are praised far and wide, especially "Three Visits to the Thatched Cottage" and "Longzhong Dialogue", which are highly popular. Zhuge Liang, who was tilling land in Nanyang, received an assignment from Liu Bei at the time of a setback and was dispatched as an envoy at the very moment of a crisis. He did all he could for his state 
throughout his life, even giving the last drop of his blood. Fan Zhongyan was a writer in the Northern Song Dynasty. Born in a poverty-stricken family, he passed the highest imperial civil service examination through great study. Guided by the principle of "taking the destiny of one's country as one's own," he remained true to the mission, although many times he was relegated due to his outspoken remarks on the monarch. He always went by the following motto: "To be the first in the country to worry about the affairs of the state and the last in the country to enjoy oneself" both when he was heading the local government and defending the frontiers. Wen Tianxiang, a famous official in the late Southern Song Dynasty, was born in turbulent times, when wars raged throughout China. When the army of the Yuan Dynasty was marching south and invading his state, he persisted in fighting the invading army; however, he was ultimately defeated and taken prisoner. Yet he stuck to his values, although he was imprisoned in "a low, dirty, dark and wet cell about $2.6 \mathrm{~m}$ wide and $10.6 \mathrm{~m}$ deep, with a low and small single-leaf door and a short and narrow white wood window." It was in this impoverished environment that he produced the masterpieces Passing Lingdingyang and Song of Righteousness, and he became a beacon of values in Chinese history.

Zou Ji, Zhuge Liang, Fan Zhongyan, and Wen Tianxiang have been memorialized by generations throughout the ages due to their noble character, forming a continuous and consistent map of values and setting benchmarks of character-forging.

At a meeting for criticism and self-criticism of the Political Bureau of the 18th CPC Central Committee, Xi Jinping made much of the self-cultivation by the leading officials of the Party. With the tales of Zou Ji, Zhuge Liang, Fan Zhongyan, and Wen Tianxiang, he exemplified that to settle down and get on with their pursuits, Party members and officials, especially senior leaders, must cultivate their moral character and mind.

"Be strict with oneself and lenient towards others"; "Seeing good deeds, I risk everything to achieve such goodness; seeing evil deeds, I immediately recoil as if I had sipped boiling water"; "All of the world's failures are due to action without authorization; all of the world's successes are the result of collaboration"; "The people who are with you because of your power will leave you when you are no longer in power; the people who are with you because of your money will scatter when your money runs out"... Many of the allusions that have been cited by Xi have been about self-cultivation. The saying, "I examine myself, day by day" teaches us the philosophies of self-reflection and self-criticism. "Hold the rules in awe" emphasizes the 
principle of abiding by laws and adhering to the bottom line "Be cautious about executing power, be cautious when you stay alone, be cautious about the erroneous ideas at the outset, and be cautious about making friends" highlights that we should be cautious about small matters and destroy evils before they pose a threat. With regard to the various aspects of settling down and getting on with one's pursuit, Xi Jinping presented the leading officials of the Party with the epistemology and methodology of morality avocation and self-cultivation.

\section{Never Hanker After Transient Success}

Taking on responsibility calls for conscientiousness. One's plans must be carried out from beginning to end, taking care to refrain from merely going through the motions or treating them as a temporary measure, like a passing gust of wind. On most occasions, a County Party Secretary serves for only a few years; however, that person should not act as if he or she were a temporary worker. Some officials are anxious to achieve quick success and obtain instant benefits within a short term of office to show their capability with ornate achievements and pave the way to promotion. This is wrong. If one's plans change every few years, a county will achieve little of substance. Instead, one should be open-minded about achievements-a good plan, as long as it is feasible, pragmatic, and answers the people's needs, should be passed down from one term of office to the next. Youyu County of Shanxi Province is situated in a windswept location in the Mu Us Desert (Ordos Desert). It is a barren land battered by sandstorms with minimal natural resources. In the early days of new China, its first County Party Secretary led the people to begin an afforestation program to curb encroachment by the sand. Over the past six decades, the successive administrations of Youyu have passed this plan on and on, retaining the same goal, leading the Party officials and people in this county to unremittingly afforest the land. Now, the greening rate of the county has risen to $53 \%$, from $0.3 \%$ in 1949 , and the "barren land" has been turned into an "oasis". Such perseverance, patience, endurance, and long-term vision are what we should be equipped with when doing any type of work.

- Be a Good County Party Secretary-Speech at the Meeting with a Class of County Party Secretaries at the Central Party School (January $12,2015)$. 


\section{Commentary}

"What is an official's reputation? You can only find the real answer from the chitchat among the people after he has retired from office." No matter how much money we gain, or how high a political reputation we have, we are subject to natural law, and we will eventually perish. What kind of achievement can maintain its glory throughout the course of history? The story of Youyu County, Shanxi Province, gives us an answer.

At the beginning of the founding of new China, the natural conditions in Youyu were very bad, sandstorms and floods wreaked havoc such that the land was sparsely populated and too arid for any plant to grow. Soon after Zhang Ronghuai, the first County Party Secretary of Youyu, assumed office, one sandstorm with overwhelming yellow sand presented a "special gift" to him. In recognition of the rugged natural environment, he embarked on the trek to investigate the environment throughout the county, with a pack on his back, a military map in his hand, and stir-fried noodles. Within only 2 months, he had traveled to more than 300 villages of all sizes and over 1000 brooks across the county and had accordingly coined a resounding slogan: "To subsist in Youyu is to plant trees in Youyu." This slogan determined the county's blueprint for development-afforesting for ecological improvement. Taking the baton from Zhang, Wang Jukun, the second County Party Secretary of Youyu, initiated the 10,000-People Afforestation Campaign. He planted trees with the people. His face became tanned as deeply as that of an average person, and his hands were covered with bleeding blisters as serious as those of average person. They even called him "Secretary Plant-Trees". The next successive secretaries handed this baton on and on and adhered to the blueprint one by one. They all followed the guiding principle, "Plant trees anywhere we can to make somewhere green first." One of them even promoted afforestation throughout his entire 12-year term of office.

Over the course of 60 years, things changed, and so did the leadership of the County Party Committee. However, the blueprint of afforestation remained unchanged. In 2015, the greening rate of the county reached $53 \%$, compared to below $0.3 \%$ before the founding of new China, increasing forested area from 533 to 100,000 hectares. With the ecological improvement, economic and livelihood conditions there improved dramatically. With the efforts successively made by the secretaries, this once "barren land" has already become an "oasis". 
Xi Jinping recounted the story of desertification control in Youyu to tell the large number of grassroots officials headed by the County Party Secretaries that to achieve accomplishments, they must be open-minded about achievements and have patience and endurance to reap long-term benefits.

Xi Jinping stressed that "a County Party Secretary should be openminded about achievements," and "a good plan should be passed down from one term of office to the next." These words represent both the philosophy of keeping the ultimate goal in mind all along and the practice of holding on straight to the end. When he governed Ningde, he demanded that the officials should overcome impatience and decrease short-term acts during economic construction. In Fuzhou, he noted, "In economic construction, the lack of long-term planning is prone to cause serious mistakes and even breed permanent regret." In Zhejiang Province, he emphasized that an official should be willing to pave the way for his successor, take over unfinished work from his predecessor, and "do his or her bit to help attain the ultimate goal based on the achievement of the predecessor..."

Telling the story of Youyu, Xi Jinping guided Party members and officials to think about and address the relationships between the individual and the collective as well as between long-term fundamental interests and personal ambitions and interests. He stressed that this concept of political achievement is a form of political ethics, which officials should firmly foster and sustain.

\section{The Great Love of Teachers}

I have read much of the deeds of many prominent teachers. Many of renown have devoted themselves to students in the spirit of selflessness. Some teachers have given financial assistance to poverty-stricken students with their limited salaries for fear of students dropping out of school. Some have purchased teaching materials at their own expense. Some have carried students on their back to school or held students' hands to help them cross over rapid steams or take dangerous roads. And some have even stuck to their posts despite disabilities. Many of these deeds are deeply moving. They all spring from the great love of the teachers. We should vigorously promote and carry forward the meritorious deeds and noble character of prominent teachers throughout our large-scale education system and even the whole of society. 
- To Be a Good Teacher of the Party and the People-Speech at the Symposium with the Representatives of Teachers and Students of Beijing Normal University (September 9, 2014).

\section{Commentary}

They impart knowledge in chalk year after year; they transmit love on the platform from generation to generation. Everyone has a cherished mentor in his memory.

As we read the newspaper and browse the Internet, we often feel moved by some story of an exemplary teacher's deeds. In Taizhou, Zhejiang Province, a teacher spent RMB 300,000 yuan over 23 years to aid needy students, while he himself lived frugally and biked to work every day; in Yibin, Sichuan Province, a disabled teacher with a single arm remained at his post in a shabby school house for 30 years; in Shiyan, Hubei Province, a female teacher who has been stationed in a remote mountain for 35 years has carried her students on her back to cross over a river hundreds of thousands of times. The great love of these teachers moves countless people.

Furthermore, some teachers have even served as the moral standards of this era. When the Wenchuan earthquake occurred, Tan Qianqiu, a teacher of Deyang Dongqi Middle School, was giving a class. He quickly organized his students to evacuate downstairs. Learning that several students had not yet left the classroom, he returned to the fourth floor. In the moment when the cement ceiling was about to fall, he shielded four students firmly under his body with open arms. When his remains were found in the ruins, he lay prone on the platform with his arms still open. Zhang Lili, a teacher of the 19th Middle School of Jiamusi, Heilongjiang Province, is hailed as "the most beautiful woman teacher." On the evening of May 8, 2012, outof-control bus rushed toward students. In the critical moment, Zhang Lili struggled to save her students and entangled herself in the rolling wheels, resulting in severe fractures of both her legs, and was eventually amputated above the knees. These teachers' deeds touched China.

$\mathrm{Xi}$ Jinping, who feels eternal gratitude to his own teachers, has made a good example of respecting teachers and attaching importance to education. He sends greetings and wishes to his teachers on the occasion of each Chinese Spring Festival. When he held public office in other places, he would take time to visit his teacher every time he came to Beijing for meetings or Party affairs. On the eve of Children's Day 2014, Xi Jinping 
visited the students of the Minzu Primary School of Haidian District in Beijing and especially invited Chen Qiuying, his Chinese teacher in middle school, who was later transferred to China Children's Publishing House. He said to Teacher Chen with a smile, "I remember when I was in the first year of middle school, you taught us Chinese and explained the texts very well."

"A teacher's indispensable, and perhaps most important quality, is the love of students," said Zankov, a Soviet educator. Telling teachers' stories on Teacher's Day, Xi Jinping elicited the deepest emotions held in everyone's heart with touching details, which not only conveyed the values of respecting teachers and education but also set an example to all teachersone should try to emulate those who are wise and good.

In Xi's view, to be a good teacher, one must have ideals and faith, moral sentiment, solid knowledge, and a benevolent heart. With these four virtues, he painted a portrait of the good teacher of the new era. "It is easy to impart expertise to others; however, it is not so easy to teach people how to be a man of virtue with profound knowledge and a noble personality." "A teacher is one who deciphers truths, teaches skills, and clarifies misconceptions." He also cited these ancient sayings to encourage teachers not only to transmit culture and knowledge but also to shape character and values.

\section{STATESMEN's Aspirations}

Wang Anshi, a statesman of the Northern Song Dynasty, was appointed Governor of Yinxian County, Zhejiang Province (now the Yinzhou District, Ningbo, Zhejiang) at the age of 27 . When he served at the post, he not only organized the construction of water conservancy facilities and developed production but also gave the people loans of official grain and defended against corruption. In addition, respecting teachers and attaching importance to education, he stressed the cultivation of talent. During his 4-year term in office, he achieved remarkable results in governance and was widely praised by the people, laying a foundation for the reforms he later introduced. Feng Menglong, a writer of the Ming Dynasty who authored the classic works Stories to Enlighten the World, Stories to Warn the World and Stories to Awaken the World, worked toward the challenging imperial civil service examination until he reached the age of 57, when he was enrolled as a senior licentiate (a professional title in feudal China). He assumed the post of the Governor of Shouning County, Fujian Province at 
the advanced age of 61 , with a term of office of 4 years. He made Shouning a county where the people lived in peace and contentment by enacting the following: alleviating the corvee, reforming the style of governing, settling lawsuits based on the principles of justice, breaking with undesirable customs, cleaning up the academic atmosphere, and promoting beneficial policies and abolishing those that were harmful. According to the records of that period, "The prison cells stood empty without any prisoners, and there was no need for a jailer to report on security."

- Speech at a Meeting for Criticism and Self-criticism of the Standing Committee of the Lankao County Party Committee, Henan Province (May 9, 2014).

\section{Commentary}

The two governors, Wang Anshi and Feng Menglong, achieved equally brilliant feats, although they were born in different dynasties. They jointly demonstrated splendid governance over the years. Wang Anshi dedicated his youth to the people on the border at the beginning of his political career, and Feng Menglong continued to struggle to serve his people into his twilight years.

Wang Anshi was a famous thinker and statesman in the Northern Song Dynasty. He was referred to as the "Chinese reformer of the 11 th century" by Lenin. As soon as he took office in Yinxian County, he began to investigate local agricultural production. Learning that the people of Yinxian County were most afraid of drought, "he vigorously organized the people to dredge the waterways and construct water conservancy facilities for water storage to cope with the drought." In the spring of the second year in his term of office, when the grain has not been harvested and the villagers have run out of their food, he lent the grain in the county-owned grain depot to the villagers and agreed with them that after the autumn harvest, they would repay the grain to the county government and pay a small amount of interest. This laid the foundation for the later promulgation of the Young Crops Law. He also valued education, establishing the Confucius Temple of Yinxian County as an institute. "From then on, Yinxian County had a county institute," according to historical records. This had a great impact on the eastern Zhejiang school of Chinese culture. 
The records state that "During his four-year tenure in Shouning, Governor Feng achieved great political progress. Who would dare say that he only has attainments in literature?" Feng Menglong was a famous writer and scholar of the Ming Dynasty. When he served at the post of the Governor of Shouning County, Fujian Province, he also commenced work based on field investigation. Concerned about the people's lack of food and clothing, he strived to achieve an agricultural production target to "reclaim land by chiseling stones and plant seedlings once a piece of sandy soil [was] reclaimed." He also placed importance on the construction of water conservancy facilities because "in general, the fields will become fertile when they are irrigated by water veins without a jam." Feng also attached importance to establishing customs and habits and disseminating culture, so that advanced culture could be introduced into the relatively backward Fujian Province. He even pursued impartial law enforcement, streamlined administration, and fair and clear punishment. During his 4-year tenure, he gained a good reputation for "promoting streamlined administration and fair and clear punishment, advocating literature first, favoring the people and treating other officials politely."

Wang Anshi was not frivolous in his youth. Feng Menglong did not muddle along in his old age. They jointly present the image of a pragmatic official in the first half and second half of life, respectively.

Xi Jinping once noted that all the grassroots officials of our Party are the reinforcing steel in the foundations of the party's edifice of governance: "They bear heavy responsibilities, yet they stand lower." In the spring of 2014, the second round of the Program of Mass Line Education and Practice got into full swing. The main recipients of this round were the Party members and officials, and the main purpose was to impress the excellent style of work of the Party into the mind of every Party member or official by extending the results of the previous round to the grassroots level. Integrating the grand theme of the second round of the campaign into impressive historical stories, Xi Jinping interpreted the value of remaining pragmatic and the people being served by the grassroots officials.

\section{“Under Jiao Yulu’s Paulownia, Their Tears Run IN SPATE"}

Comrade Jiao Yulu lived a simple life, working diligently and frugally, and he practiced the principle "to be the first to bear hardships and the last to enjoy comforts." His clothes, hat, shoes, and stockings were all old and had 
been washed many times, and all the worn items had been mended and sewn innumerable times. He strictly observed party discipline and never used his power to benefit himself or his relatives. The Ten Never-Do's for Officials drafted by him included specific provisions on honesty and self-discipline for officials. Yesterday, standing in front of the display board of the Ten Never-Do's for Officials in the Memorial Hall for Comrade Jiao Yulu, I read it again carefully. I think these provisions are on-target and emphasize the rules. Thus, we should not juggle our words, making regulations that are grandiose but vacuous. In addition to the provision "never accept a complimentary opera ticket," the Ten Never-Do's for Officials stipulated, "Opera tickets for seats in the front ten rows should not be sold only to officials." This was meant that some favorable tickets should be left for the masses. Once, when he overheard that his son had not paid for a show because he knew the ticket seller, he chastised him never to seek any personal privilege and "freeload", and he ordered him to send the money to the theater. His character of being strict with himself and refusing to be contaminated by evil influence vividly reflected his self-consciousness of strengthening Party discipline.

- Speech at the Enlarged Meeting of the Standing Committee of the Lankao County Party Committee of Henan Province, (March 18, 2014).

\section{Commentary}

In August 1922, Jiao Yulu was born into a poor family in Zibo, Shandong Province. He volunteered to be a militiaman as early as 1945 and joined the CPC in 1946. In 1948, he went southward with a work team, and he later was transferred to Lankao County, Henan Province to be the County Party Secretary of Lankao. In the position of the County Party Secretary of Lankao, he manifested his immovable faith and forged a spiritual monument to the communists.

During 1962 and 1964, Lankao was under "three serious threats"waterlogging, sandstorm, and saline-alkali land. Together with the officials and the masses of the county, he conducted small-scale experiments. These included digging out the silty soil to repress the sands, digging out the silty soil to repress the alkali, and enclosing the sand dunes. Based on the experimental results, he summarized specific strategies for eliminating the "three 
serious threats" and explored methods of large-scale paulownia planting. During that period, Jiao Yulu, who was suffering from liver cancer, endured intense pain and yet continued to work. Through painstaking efforts, he led Lankao to achieve remarkable results in eliminating the "three serious threats." He led the masses to plant paulownia to develop windbreaks and for sand fixation. Since then, planting paulownia has become the major industry in Lankao, and the annual output value reached more than RMB 6 billion yuan by 2014. The sand-proof tree became a moneymaker for the people. Although Jiao Yulu spent a short time in office in Lankao, he bequeathed the spirit of Jiao Yulu-treat and love the people as family, struggle hard, remain scientific and pragmatic, brave difficulties, and contribute selflessly. This spirit is of eternal value.

Xi Jinping has repeatedly told the story of Jiao Yulu. He has often recalled when he learned the deeds of Jiao with deep emotion, relating the following: "On February 7, 1966, when I was in the first grade of middle school, the People's Daily published a lengthy newsletter from Mu Qing and other comrades-The Example of County Party Secretaries-Jiao Yulu. My politics teacher choked with tears many times while reading this newsletter for us. I was especially deeply shocked when I heard that Comrade Jiao Yulu still persisted in his work during later-stage liver cancer, with a stick pressed against the liver area. The other end of the stick made a big hole in the right side of the chair..." Since then, the spirit of Jiao Yulu has been deeply rooted in Xi's heart, inspiring great spiritual power. "Of all the citizens, who does not love a good servant? Under Jiao Yulu's paulownia, their tears run in spate." These are the words of the Niannujiao-Memories of Jiao Yulu, written by Xi Jinping to express his respect for and cherish the memory of Jiao Yulu.

The story of Jiao Yulu has been passed down from generation to generation, and his spirit has eternal value. Xi Jinping has repeatedly stressed, "County Party Committees are the 'first line command' of governance for our Party" and that "With their responsibilities growing and becoming more diversified, county governments now play an important role in building a moderately prosperous society in all respects, in driving reform to a deeper level, in implementing the rule of law, and in strengthening Party discipline." At the Enlarged Meeting of the Standing Committee of the Lankao County Party Committee, Xi Jinping led the Party members and officials to review the spirit of Jiao Yulu for the purpose of inspiring the numerous County Party Secretaries to learn from Jiao and strive to be 
a County Party Secretary like Jiao Yulu, urging them to fulfill the requirements of "with the people in mind, with responsibility in mind, and with self-discipline in mind."

\section{WORDS AND DEEDS}

There is a couplet hung in the ancient yamen in Neixiang County, Henan Province: "As an official, do not have prejudice on your job because it is you the officer on whom the civilians rely to address even trivial matters; do not bully the civilians since it is they who raise you up and one of whom you are." It reveals the relationship between officials and the people in words that are easy to read and understand. Even the feudal officials had such political consciousness, us, the communists of today, should have much better understanding of the relation between the people and the power that they grant us. Not long ago, an internal reference from the People's Daily introduced the thoughts on politics of Gao Derong, Deputy Director of the Standing Committee of the National People's Congress of Nu Jiang Lisu Autonomous Prefecture, Yunnan Province. I was deeply moved after reading his thoughts. This official of Dulong nationality said, "Leaders are the people who lead the masses to work together, to work out a way"; "If an official or a leader is not pragmatic, he will turn from a conductor into a muckraker"; "We should conduct others with our deeds, not words"; "If you float in officialdom, then you will be more and more impetuous; and if you live amid the masses, then you will be further enriched." I would like to recommend these words to all of you for mutual encouragement.

- Speech at the Symposium with the Principal Leaders of Heze, Shandong Province and the Counties and Districts Under the Jurisdiction of Heze (November 26, 2013).

\section{Commentary}

"As an official, do not have prejudice in your job because it is you the officer on whom the civilians rely to address even trivial matters; do not bully civilians since it is they who raise you up and one of whom you are." This is a couplet hung on the columns of the Self-Examination Hall in the ancient yamen in Neixiang County, Henan Province. It was composed by Gao Yiyong in 1680, the 19th year of the reign of Emperor Kangxi. At that time, 
Gao was Governor of Neixiang County. He was born in Jiaxing, Zhejiang Province. In 1679, when he was appointed as Governor, the county of Neixiang was in chaos caused by war such that a great deal of civilians had left their hometown, the land was deserted, and the economy was depressed. Extremely worried about this plight and feeling heavily responsible, he was sleepless at night and composed this couplet by candlelight.

Tolerant and benevolent, Gao took good care of the people. When he traveled to the provincial capital Daliang (present-day Kaifeng), the civilians there pointed to him and said admiringly, "This is Officer Gao, Governor of Neixiang County." When he left the post, the civilians of Neixiang lined the streets to retain him, and someone even ran after him hundreds of miles to see him off. The Encyclopedia of Decrees and Regulations of Neixiang compiled during the reign of Emperor Tongzhi provides a comment on him: Gao Yiyong, who reclaimed a large amount of land and cracked down on bandits, made a great contribution to Neixiang.

Gao Derong is a typical leader of today. Always bearing in mind his countrymen of Dulong nationality, he resolutely returned to his hometown twice during his career. The first time he made this decision was when he was young. At that time, he had left the remote mountain area and faced an opportunity to work at his college after graduation. However, he applied to be sent back to his hometown, the remote Dulong River Town, to teach. The second time was after he had reached the age of 50 . When he was promoted to Deputy Director of the Standing Committee of the National People's Congress of Nu Jiang Lisu Autonomous Prefecture, Yunnan Province, he applied to the organization once again, "Please set my office in Dulong River Town." Further, he gave an unpretentious and touching reason: "My countrymen of Dulong nationality still live in poverty; thus, I am unable to have peace of mind if I live in ease and comfort away from the mountain."

In addition to caring for the people, Gao Derong also advocated pragmatism. He traveled over a hundred miles in the mountain region per day, from the early morning until night, to visit six villages and dozens of construction sites. This was the normal working mode of this old county mayor. To build a long tunnel under the alpine snow line, he busied himself coordinating the work of various departments and governments at all levels for 3 years until the tunnel was completed.

Working among the masses and serving as a good example for the masses is a fine tradition of our Party. In November 2013, Xi Jinping visited Heze, 
Shandong Province, for an inspection. At the symposium with the principal leaders of Heze and of the counties and districts under Heze, he began his talk with the couplet hung in the ancient yamen in Neixiang and linked it to the deeds of Gao Derong, endowing the people-oriented thought of ancient times with contemporary significance and tracing the current spirit of "for the people" back to its historical origin. Telling these stories, President Xi reiterated the pragmatic style and mass consciousness with which leading officials should be equipped, restated the metaphorical relationship between a ship and the water, and recalled the interdependence between the CPC and the masses. His intention was to guide the leading officials to continue to bear hardships and to live and work with the masses through governance that aims at the happiness of the masses. He shared Gao Derong's thoughts with the whole Party: "We should conduct others with our deeds, not words," mirroring present-day misconduct.

\section{The Power of Faith}

In the revolutionary wars, martyrs defied all difficulties and dangers and took death calmly because of their unswerving commitment to lofty ideals and faith. Six members of Chairman Mao's family sacrificed their lives for the revolution. The Senior General Xu Haidong's clan sacrificed over 70 members. In Marshal He Long's clan, we can find 2,050 identified martyrs. Why were these revolutionary predecessors willing to devote their lives unselfishly and heroically? Reasons include espousing a noble revolutionary ideal, upholding a lofty political faith, seeking the complete overthrow of the evil old regime in China, and striving to achieve national independence and the people's liberation. I have read Honest Poverty, which was written by the martyr Fang Zhimin in the prison, many times. It expresses the older generation of communists' loves and hates. It defines true poverty and wealth and the greatest happiness, and it describes the great faith of the revolutionists and what a valuable life looks like. Every time I read it, I am inspired and enlightened.

- Leading Officials Should Have the Correct Outlooks on the World, on Power and on Career-Speech at the Opening Ceremony of the Central Party School in 2010 Autumn Semester (September 1, 2010). 


\section{Commentary}

Six family members, over 70 clansmen and clanswomen, and 2,050 martyrs: these astounding figures illustrate the aspiration and faith of communist' values.

Six members of Chairman Mao's family sacrificed their lives for the revolution, including his wife Yang Kaihui, eldest son Mao Anying, eldest younger brother Mao Zemin, second younger brother Mao Zetan, younger female cousin Mao Zejian, and nephew Mao Chuxiong. He sacrificed nearly his entire family for the revolution. When he was informed of Mao Anying's sacrifice on the Korean battlefield, the first thing he said from extreme distress was "This is his fate, as the son of Mao Zedong!" These words expressed the father's solicitude, and they even manifested a communist's immovable faith and spirit of dauntlessness. Marshal He Long often said, "It was the need of the revolutionary cause that all martyrs in our clan died for the country; thus, we do not constantly mention ourselves." This dedicated spirit of sacrifice of family and individual interests for one's country and for the collective benefit precisely advanced the success of the revolution in China.

Fang Zhimin is arguably an outstanding representative of the countless martyrs laying down their lives for our nation. When he was captured on the battlefield, what astonished the Kuomintang soldiers was that, as a criminal the Kuomintang wanted most and a "high official" of the CPC, he did not even have a copper coin in his pocket. After being captured, he refused the coaxing and lure of the high-ranking officials of the Kuomintang, and when the Kuomintang led him through the streets to warn the public, he remained defiant and unyielding. In prison, he produced literary works such as Beloved China, Honest Poverty, A Record of My Life in Prison and A Brief Account of My Revolutionary Struggle despite the extremely poor conditions. These books have become the spiritual food for later generations, inspiring countless communists. As he wrote in Honest Poverty, "Honest although poor, we are living a clean and simple life-this is how we revolutionists can overcome innumerable difficulties!"

At the opening ceremony of the Central Party School in the 2010 autumn semester, Xi Jinping told the stories of the communists of older generations to inspire the present-day Party members and officials to fortify their ideals and beliefs and to consolidate the pedestal of their faith. Faith, the most beautiful word in human society, is the foundation for over 88 
million communists to settle down and get on with their pursuit. Xi has repeatedly called on all party members "to stick to the lofty faith to achieve indestructibility" since the 18th National Congress of the CPC.

The column "People's Tribune" of the People's Daily once published the article The Flavor of the Faith, which narrates the anecdote that when Chen Wangdao was concentrating on translating The Communist Manifesto, he mistook ink for brown sugar and ate it unconsciously. This story embodied the sweet flavor of the communists' spirit and faith. To stimulate Party members and officials to maintain their ideals and maintain their faith, $\mathrm{Xi}$ Jinping repeatedly told this touching story from the Party's history, repeatedly stressing that "ideals and faith are the spiritual nutrition of communists," and he repeatedly warned that "nothing is more dangerous than to waver in ideals and faith; nothing is more dangerous than the slide of ideals and faith."

\section{“We Must Save Him, Even If We Have to Go Begging"}

In a remote village, the Party Branch Secretary Zheng Jiuwan fell ill. To cure him, the villagers spontaneously raised tens of thousands of yuan within one day for his operation. They said, "We must save him, even if we have to go begging." Some officials of the village even lamented, "If I fall ill, how many villagers will save me?" The villagers did this to repay the contributions made by Zheng Jiuwan, and the scales in their hearts proved the weight of this grassroots Party official. Through practical actions, he revealed the connotation of the saying, "The civilians value the officials as highly as the officials value the civilians." This is the significance of Zheng Jiuwan as a worthy role model.

- Serve the People, and Win the People's Support (July 24, 2006), from Fresh Ideas of Zhejiang.

\section{Commentary}

Zheng Jiuwan was Party Branch Secretary of Houjiujiang Village, Shankeng Town, Yongjia County, Wenzhou, Zhejiang Province. In the early hours of October 5,2005 , he suddenly had a cerebrovascular rupture due to long-term overwork and was in danger of dying. To raise money for his operation, the villagers of this remotest village in the town, where the 
per capita income was only approximately RMB 2,000 yuan, unexpectedly scraped together nearly 70,000 yuan within a single day. One villager, Liu Liangli, had 7,160 yuan, which was prepared for paying for the chicken feed needed by his chicken farm. His wife said, "We can recover, although we will lose all the chickens. But, the Secretary will not come back if his illness is not treated immediately!" Therefore, he donated 7,100 yuan, with only 60 yuan left for his family. After that, he further donated 100 yuan that he borrowed to pay his electricity bill. Chen Jurui, Director of the Women's Congress of the Village, donated over 1,300 yuan from her life savings. This was the money that her daughter had given her at the Chinese Spring Festival and other festivals. Liu Songyun, who was suffering from severe hepatic ascites and whose family was in financial distress, sent 300 yuan to Zheng Jiuwan through others. He had earned the 300 yuan by selling eggs, persimmons, and soybeans and had saved the money to buy medicine... "We must save Jiuwan, even if we have to go begging," said the villagers. Those villagers who were able to walk went to the hospital with water and wheat cakes to wait for him. After the first operation failed, people from all sectors of society made generous contributions of funds. Subsequently, the secretary was out of danger and soon recovered.

"One loving others is always loved by others." Upon joining the CPC, every Party member took an oath of loyalty. Zheng Jiuwan carried out his oath by serving his people throughout his career since he became the Party branch secretary a dozen years ago. There are several touching stories. When he learned that Chen Jurui's husband had undergone a hyperosteogeny and was in urgent need of money to treat the disease, he immediately sent her 2,180 yuan, which he had earned by selling his cattle in preparation for his son's marriage, and he told the patient to have a good rest. After the villager Liu Guangmiao's leg was broken in a tractor accident, not only did Zheng pay several hundred yuan for Liu's medical expenses and give him 50 yuan to buy food but he also helped his family to harvest potatoes and grow winter wheat. Zheng Jiuwan was not very well off to be sure; however, he contributed as much as he could to the villagers.

The touching stories between Zheng Jiuwan and the villagers reveal the interdependent relationship between leading officials of the Party and the masses. Learning about Zheng's deeds, Xi Jinping, as Secretary of the Provincial Party Committee of Zhejiang, gave the following instructions: "The civilians value the officials as highly as the officials value the civilians. 
The advanced deeds of Comrade Zheng Jiuwan were actually the embodiments of this saying."

$\mathrm{Xi}$ Jinping told Zheng Jiuwan's story in Fresh Ideas of Zhejiang to highlight that all members and officials of the CPC should put the people at the very center of their hearts. After the 18th National Congress of the CPC was held, "the people" became key words in all important speeches delivered by General Secretary Xi Jinping: "The people are the source of our strength"; "Highest-level politics are about popular support, and justice is the strongest force"; "The people aspire to a decent life-that is what we are fighting for"; "Rely closely on the people to promote reform and opening up"; and "To realize the Chinese Dream, we must pool China's strength, that is, the strength of great unity among the people of all ethnic groups." At the Celebration Ceremony of the 95th Anniversary of the Founding of the CPC, he gave special emphasis to the CPC's "original aspiration", and "the people" as the very center of the "original aspiration".

\section{Gu Wenchang's Hidden Achievement}

The masses and Party officials in Dongshan County, Fujian Province admire $\mathrm{Gu}$ Wenchang, their former County Party Secretary. This is because Gu neither pursued "conspicuous achievement" nor attracted public attention when he was in office; instead, he took more than a dozen years to lead local officials and the masses to build a shelter forest along the coast for later generations. This is an immortal monument in the people's hearts. Such a "hidden achievement" is the greatest "conspicuous achievement".

- "Hidden Achievement" and "Conspicuous Achievement" (January 17, 2005), from Fresh Ideas of Zhejiang.

\section{Commentary}

In Dongshan County, Fujian Province, there is a custom that has been passed down: at an ancestor worship ceremony, pay tribute to Secretary Gu before worshipping one's family ancestors. Each year during the Chinese Spring Festival and other festivals, local families offer sacrifices to pay tribute to Gu Wenchang, the County Party Secretary they most respect.

Today's Dongshan is a beautiful and richly endowed ecological island, offset by flower fields and surrounded by trees. To everyone's surprise, over 
60 years ago, it was a desolate sand island where sandstorms wreaked havoc and the land went out of cultivation. There were more than 150 days per year with force- 6 strong winds or stronger, and the greening rate was only $0.12 \%$. For one hundred years, sandstorms constantly engulfed people's homes, and smallpox and eye diseases spread around the county. At least one-in-ten residents survived as a coolie or a beggar.

The Australian Pine Tree forest was precisely the key to reviving the island, and a "monument" was built there by Gu Wenchang. Gu Wenchang was born in Linxian County, Henan Province. He traveled southward with troops to Fujian Province in 1950. Then, he worked in Dongshan County for 14 years and acted as the County Party Secretary for 10 years. He was known to say, "Overcome the sandy wind, or be buried by it." With such courage, he led the Dongshan people to struggle against the sandy wind for more than a dozen years by planting Australian Pines around the island as a Green Great Wall. Finally, they triumphed over the traditionally unbeatable sandy wind, making the island a peaceful home for the people.

Later, Gu Wenchang was transferred to the Fujian Provincial Department of Forestry as Deputy Director General. During the Great Cultural Revolution, he was sent to work as a regular worker. Wherever he worked and fought, the people all had the greatest respect as well as endless affection for him. When he was in office, he always stood at the forefront of the struggle against the sandy wind, the forefront of afforestation and the forefront of reservoir construction. In the early days after the founding of new China, he put forward the proposal of renaming "the enemy's and puppets' dependents" as "the war-affected dependents." This benevolent policy won him the support of 100,000 people. He often said to his family and those around him, "As leaders, we must keep straight with clean hands." None of the personnel working for him was promoted or put in an important position by him. None of his five children were awarded assignments to an official position. He did not allow his family to use even a bicycle because it belonged to the public.

"I expect to be with the people and the trees of Dongshan forever" were Gu Wenchang's last words as he approached his end. Now, he is sleeping his eternal sleep in the Chishan Forest Farm where he combated nature. The trees he planted more than 50 years ago tower like a canopy and guard his tomb. They witnessed the passion and loyalty of this good official "with the Party, the people, the responsibility and self-discipline in mind." 
Xi Jinping has praised three County Party Secretaries: Jiao Yulu, Gu Wenchang, and Wang Boxiang. In Fresh Ideas of Zhejiang, taking Gu Wenchang as an example, he discussed the truth in "hidden achievement" and "conspicuous achievement". There is no immediate payoff when one plants trees; however, it is an effort that will bear fruit after several decades of effort and the "hidden achievement" will grow into a "conspicuous achievement". In Xi Jinping's opinion, "hidden" and "conspicuous" are contradictory and unified contradictions. "Hidden" is the basis of "conspicuous", and "conspicuous" is the result of "hidden". The later generations always engage in work based on the foundation laid by their predecessors. If you do not pave the road and are unwilling to contribute in obscurity, then the "conspicuous achievement" will be out of the question, and the "seemingly conspicuous achievement" in front of you will at best obtain the transient success of an "image project", just like a tree without roots or water without a source.

\section{Marx Produced Capital: A Critique of Political Economy}

\section{POVERTY}

A quick look at human history reveals that the people who accomplished great things were those who had great character. Karl Marx finished writing Capital: A Critique of Political Economy when he was at his most destitute. In February 1852, he wrote a letter to Engels saying, "A week ago I reached the pleasant point where I am unable to go out for want of the costs I have in pawn and can no longer eat meat for want of credit." However, even then, Marx did not yield. He refused to stop working. Defying hardships while staying true to the doctrine shows the moral courage of a revolutionary proletariat.

- A Chat About Entering Public Service (March 1990), from Up and Out of Poverty.

\section{Commentary}

Karl Marx, as the spiritual adviser of the communists, told us what the phase "moral courage" means through lifelong struggle. When he started writing Capital: A Critique of Political Economy in London, he was experiencing one of the toughest period of his life. His family was plagued with starvation 
and survival threat because of a lack of a fixed source of income, coupled with the persecution and blockade of the bourgeois government. Under the double threat of starvation and disease, Marx poured out his bitterness in a letter to Engels, saying, "My wife is ill and little Jenny, too. Lenchen caught a disease called 'neurogenic fever'. I was unable to send for a doctor before. And now, still, because I have no money to buy medicine. Over the past eight-to-ten days, we have only had bread and potatoes to eat. Yet it is still uncertain whether we can get them today." Three of his six children died in such poverty, and he had no money with which to buy them small coffins.

Marx lived in poverty throughout his exile in London. When he was too poor to pay the rent, his landlady called the police to seal up his family's bed, clothes, and even the cradle and toys of his children. The children were scared to hide in the corner and secretly shed tears. Marx had no alternative but to look for lodging in the rain. However, nobody was willing to take them in. At the same time, the owners of the drugstore, bakery, and milk shop all came to press them for payment of their debts. Faced with the creditors, Jenny, his wife, took their bed with the intent to sell it off to pay their debts. Unfortunately, just after she had lifted the bed into the cart, the police came again, saying that they had violated the law by transporting things at dusk and that they were trying to evade their debts. For Marx, the only function of money and life was to sustain his revolutionary cause. He once wrote in a letter that, "If I could obtain enough money, slightly more than nothing, to raise my family and finish my book, then I would not mind being sent to the stripping yard, in other words, being executed."

Marx was born into a rich family. He got a doctor's degree at the age of 23 and at 25 married a girl of the nobility, the daughter of the Chief Editor of Rheinische Zeitung. He should have been "Duke Marx," "Minister Marx," "President Marx," or "Professor Marx"; however, he gave up all such titles and chose the profession that was, according to him, "best for human welfare." For his work and the revolutionary cause, he lived a vagrant life in utter destitution for 40 years, during which time he witnessed the early death of his children. In March 1883, he died at his desk. With his actions, he embodied the moral courage of a revolutionary proletariat.

Xi Jinping has cited Marx's story of producing Capital: A Critique of Political Economy to reiterate a truth: moral courage is a quality that everyone who aims to accomplish great things must have. No matter what difficulties and obstacles one faces, he can overcome them and attain success as 
long as he holds to his faith and sustains moral courage. At present, Party members and officials are faced with all types of temptation and undermining thoughts amid reform challenges and transformation pressures. Therefore, Party members and officials should brush up on Xi's earnest words, for example, "A quick look at human history reveals that the people who have accomplished great things must have great character" and "Moral courage is a quality every leader must have." These words will specifically encourage a firm belief in their ideals and faith and inspire moral courage so they can refuse to be contaminated by the temptation, stand firm when confronting undermining concepts, and have the courage to struggle against risks and challenges. By doing so, the great vessel of "China" will cleave through the waves and head to open waters.

\section{Water Droplets Drilling Through Rock}

Upon settling in the countryside, I saw firsthand the power of dripping water drilling through rock. That image, which captured the spirit of persistence, has stayed with me all these years. It has become a well-worn source for contemplating life and movement.

Rock and water are two opposing elements that are used to symbolize dogged stubbornness and gentle fluidity. Yet despite being "gentle", water will drill through "solid" rock over time.

As a metaphor for people, this is the embodiment of a certain moral character: it is the willingness to rise to fight each time one falls and the courage to sacrifice oneself. A single drop of water is small and insubstantial. It will die a cruel "death" in any battle with a rock. Yet in that brief moment of "sacrifice", although it cannot see its own value and achievement, it is one of countless drops of water that have already fallen and thus triumph by finally drilling through the rock. From the perspective of history or the development of an economically disadvantaged area, we should not seek personal success and fame. Instead, we should strive to make steady progress, one small step at a time, and be willing to lay the groundwork for overall success. When everyone doing their work models themselves on a droplet that is ready to sacrifice itself for the greater good, we need not worry that our work is not important enough to make a lasting change.

When I describe my awe upon seeing the power of droplets drilling through rock, I am praising those who have the willingness to rise each time they fall and the moral character to sacrifice themselves for overall 
success. I wish to express my admiration for those who develop a social plan and have the tenacity to see it through to the end.

- Water Droplets Drilling Through Rock (March 1990), from Up and Out of Poverty.

\section{Commentary}

Though the power of water droplets is negligible, they are single-minded and persistent. Hence, they can drill through rock. In the Taiji Cave in Guangde County, Anhui Province, there is a rabbit-shaped rock with a pit formed by the drilling of water droplets. In the Bodhisattva Lamasery of the Wutai Mountain in Shanxi Province, a dripping eave has had droplets drip on to the stone steps, which formed porous pits.

The Chinese idiom “滴水穿石” (which means water droplets drill through rock) is often used as a metaphor to explain that one can attain great achievements by persevering unremittingly, despite one's negligible power. This idiom was originally used by Zhang Guaiya, a famous official in the reigns of Emperor Taizong and Emperor Zhenzong of Song. When he served as Governor of Chongyang County, the social atmosphere there was very poor, theft was rampant, and the money in the treasury of the county government was frequently stolen. Therefore, he became determined to crack down heavily on this social malady. One day, seeing a low-level official who administered the treasury coming out of the treasury in a panic, Zhang speculated that the treasury official might embezzle the money in the treasury, thus asking his valets to search the official. Finally, a copper coin was discovered in his turban. The official excused himself, saying "It is just a single copper coin. No big deal." Then, Zhang wrote in red with a Chinese brush, "One coin is stolen per day, one thousand coins would have been stolen after one thousand days. A rope can cut wood, and water droplets can drill through rock." This meant that if one steals a single copper coin every day, then one thousand coins would have been stolen after one thousand days; if one ceaselessly attempts to cut a piece of wood with nothing but a rope, the wood will ultimately be cut; and if water droplets drip onto a rock one by one without stopping, the rock will eventually be drilled through. Since then, the vice of theft in Chongyang County was kept in check, and the social atmosphere was significantly improved. 
From September 1988 to May 1990, Xi Jinping served as Secretary of CPC Ningde Prefectural Committee. At that time, Ningde was recognized by the State Council as one of the 18 contiguous poverty-stricken areas in China. Xi Jinping traveled through all the nine counties under Ningde within the first 3 months after he assumed office, and after that, he further visited throughout the vast majority of towns and villages there to fully pull eastern Fujian out of poverty. When he left the post from Ningde, 94\% of the poverty-stricken households in the region had their problems of needing food and clothing solved. The People's Daily even made a special report on this, themed as "Ningde Lifted Itself up and out of Poverty". Impelled by Xi Jinping, Ningde continued to strive in the spirit of "water droplets drill through rock" and "the weak bird starts flying early" (a frequently used Chinese idiom which means a person or group that has to compensate for their weaknesses by working hard). For instance, Chixi Village in the county carried out poverty relief on site during the first 10 years after it set off poverty alleviation; in the second 10 years, it further alleviated poverty by relocating the villagers to the central village; and during the third 10 years, it developed the "tourism + industry" and eventually embarked on the road toward a moderately prosperous society. In 2015, $\mathrm{Xi}$ Jinping summarized the poverty alleviation experience of this story of "China's top village in poverty alleviation" in a sentence: "Water droplets drill through rock by persevering unremittingly."

In those years, the reform and opening up policy opened China up to the world, and Ningde was in the initial stage of poverty alleviation, during which time it was impoverished and enfeebled. Xi Jinping told the story of "water droplets drill through rock" to inspire leaders and officials at all levels with confidence, boost their morale, and stimulate them to hold firm their resolve toward poverty alleviation and to continue to persevere. Today, standing at a new historical starting point, China is heading for a higher realm of development. Yet $\mathrm{Xi}$ is still anxious about the people in the depressed areas, often saying, "The people who evaluate our achievements in building a moderately prosperous society are the peasants," and "To build a moderately prosperous society in all respects, we should not leave any minority ethnic group behind." By saying these words, he inspired leaders and officials at all levels to achieve overall success in poverty alleviation by developing a great plan and then having the tenacity to see it through to the end. 


\section{They Irrigated the LAND of China with Their Blood}

The first generation of communists in Zhengding advanced the freedom and liberation of their hometown and home country wave upon wave. They were the outstanding children of the Zhengding people, and the land of their hometown was irrigated with their blood. Comrade Yin Yufeng and Hao Qingyu were their prominent representatives.

Yin Yufeng was born in Zhoutong Village, Zhengding County. Joining the CPC in 1924, he was the first County Party Secretary of Zhengding and held the post until his death in 1928. Hao Qingyu was influenced by the progressive ideological trend at as young as age of 14 and soon became a member of the Party. He returned to his hometown in 1924, and from then on, he worked with Comrade Yin Yufeng and other comrades to make great efforts to establish the organization of the CPC. In the summer of 1925, the British and Japanese imperialists brought about the May 30 Incident in Shanghai. Then, Yin Yufeng, Hao Qingyu, and other comrades organized the Zhengding Backup Team for the Shanghai Incident. They mobilized the people of Zhengding to economize on food and clothing to assist the families of the victims in Shanghai, and they led a mass rally and a students' strike, starting an anti-imperialist movement in Zhengding.

In June 1927, they led the famous Zhengding Peasant Uprising on behalf of the Zhengding County Committee of the CPC because the clique that had settled in Zhengding concocted pretexts to collect 3 years' land tax in advance from the people and levy "Taochijuan" (which means compelling the people to make donations to suppress the communizing National Revolutionary Army) on the people. All of these actions aroused discontent among the whole county. On Lunar May 17, the day of the Town's God Temple Fair in Zhengding, more than 10,000 people came to the fair from dozens of miles around. At around 10 a.m., someone raised a big white flag in the theater square with the words, "Zhengding Peasants' Petition Against Taochijuan" in red. Then, the people swarmed in the square from all directions, with holding broadswords, spears, and shovels, and they rushed to the county government in a formidable array. Comrade Hao Qingyu, who had practiced martial arts in his youth, was always at the forefront of the parade. He led the masses and rushed the lobby of the government office and then smashed the screen in the lobby with a doublejoined cudgel, scaring all the officers. In the end, under pressure from the masses, the county governor set forth the pledge to "abrogate Taochijuan" and "postpone the collection of the land tax" and announced the pledge to 
the whole county. This uprising hit the arrogance of the Fengtian clique, and it cultivated and trained the Party officials of Zhengding, laying the foundations for the revolutionary victory to come.

In 1928, Comrade Yin Yufeng, who broke down from constant overwork, died of illness at the young age of 24. Comrade Hao Qingyu grew up rapidly in the struggle of the masses and became an outstanding organizer and leader of the northern peasant movement of our Party. He was arrested in Tianjin in 1931 due to the betrayal of a traitor, and he died in 1935 at the age of 32. All the people like Yin Yufeng and Hao Qingyu, who have made contributions to and sacrificed their lives for the Chinese nation and their hometown, made a glorious mark in the patriotic history of Zhengding County. Many of them did not even leave their names, but they continue to be revered by the new generations and will always inspire later generations to devote their efforts and even lives to achieving the prosperity of the motherland and of their hometowns.

- Know It Deeply, Love It Deeply (Preface), from the Know It Deeply, Love It Deeply, Edition 2015, published by Hebei People's Publishing House.

\section{Commentary}

Lu Xun once said, since ancient times, we have people among us who have toiled hard at work, who have pushed through obstacles to get things done, who have pursued truths at all costs, and who have pleaded to the authorities on behalf of the needs of ordinary people. They constitute the backbone of China. Perhaps their lives have gone, but their spirit will be always in the hearts of the people. Yin Yufeng and Hao Qingyu were such heroic figures.

Hao Qingyu was born in Zhengding County, Hebei Province. He went to Beijing to become a shoemaker in 1918 and joined the CPC in 1924. Together with Comrade Yin Yufeng and others, he did a lot of work for the establishment of the Party organization in Zhengding. To appoint liaisons and disguise the roles of Party members, he founded the "Yuhua Shoes Shop", which played an important role in the development of the Party organization in Zhengding. After that, the Zhengding Party organization was expanded and restructured several times, and it developed from a special branch into the central county committee and then the local committee, 
becoming the leading force in the people's revolutionary struggle in that area. Having the aim of mobilizing the masses, Hao went deep into the farmland and tirelessly traveled to poor peasants' cottages to propagate the truth of revolution. A communist among the rural instructors described him, "He walked in the fields by day, slept in a haystack at night, satisfied his hunger with prepared solid food and quenched his thirst with cold water."

In the spring of 1928, Hao Qingyu was transferred to Tianjin and appointed as the member and Minister of the Peasant Movement Department of Shunzhi Provincial Committee of the CPC. In the summer of 1930, he assumed the posts of the member of the Standing Committee of Shunzhi Provincial Committee, inspector of Shunzhi Provincial Committee, and Secretary of Baoding Ad-Hoc Committee of the CPC. Recalled to the Shunzhi Provincial Party Committee in March 1931, he was arrested and sent to prison in Tianjin in 1931 due to the betrayal of a traitor. In prison, Hao still displayed unyielding integrity although he was seriously ill. The enemy took advantage of his illness to entice him into putting his fingerprint on an "Anti-Communist Notice", saying, "Let us apply some ink to your finger. Just press a fingerprint here, we will send you out and to the German hospital to treat your illness, otherwise you will be sent to the overbridge (an execution ground)!" Hao Qingyu replied without hesitation, "You Kuomintang surrender to Japan and oppress our people, you should reflect on that. I will resist against Japanese aggression to the end and never repent. You can send me anywhere as you wish!" In September 1935, Hao Qingyu died in prison.

With regard to these heroes of Zhengding whom Xi Jinping introduced, their deeds may be little known and their names may be unknown to the public; however, they strove against the oppressors of history; they irrigated our great land with their blood as they pursued their faith. They constitute the backbone of China, and their integrity and spirit will lead us, a nation with a long history, to revive. Xi Jinping learned about their deeds while he was heading the administration of Zhengding, and he encouraged their spirit in the officials of Zhengding. To this day, these deeds can still bring spiritual energy to Party members and officials. Xi Jinping attaches great importance to heroes, and he cherishes them. He has emphasized on many occasions that we should revere heroes, defend them, learn from them, and care for them. At the Ceremony of Awarding the Commemoration Models of the 70th Anniversary of the Victory of the Chinese People's War of Resistance Against Japanese Aggression, he recited a host of heroic teams, 
including the "Langya Shan Five Heroic Men", the "Liulangzhuang Company" of the New Fourth Army, the "Eight Female Soldiers" of the Northeast Counter-Japanese United Army, and the "Eight Hundred Heroes" of the Kuomintang Army, to pay tribute to the heroes in the name of the state. As Xi said, all national heroes, including those who resisted against Japanese aggression, are the backbone of the Chinese nation, and their deeds and spirit are powerful forces that inspire us to move forward.

Open Access This chapter is licensed under the terms of the Creative Commons Attribution-NonCommercial-NoDerivatives 4.0 International License (http:// creativecommons.org/licenses/by-nc-nd/4.0/), which permits any noncommercial use, sharing, distribution and reproduction in any medium or format, as long as you give appropriate credit to the original author(s) and the source, provide a link to the Creative Commons license and indicate if you modified the licensed material. You do not have permission under this license to share adapted material derived from this chapter or parts of it.

The images or other third party material in this chapter are included in the chapter's Creative Commons license, unless indicated otherwise in a credit line to the material. If material is not included in the chapter's Creative Commons license and your intended use is not permitted by statutory regulation or exceeds the permitted use, you will need to obtain permission directly from the copyright holder.

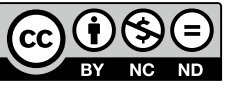

